\title{
Om Grundtvigdebatten \\ med svar til mine kritikere
}

\author{
Af William Michelsen
}

1. Da vi i sin tid stiftede Grundtvig-Selskabet og startede Grundtvig-Studier, var hensigten den at indføre et forum for en saglig Grundtvigdebat. Et sådant eksisterede ikke i 1947, hvor mærkeligt det end kan lyde i dag. Det videnskabelige studium af enkelte forfattere blev foretaget og drevet af enkeltpersoner, som arbejdede hver for sig på, hvad der eventuelt kunde blive til en doktordisputats - hvis arbejdet blev antaget til forsvar for doktorgraden - og ellers næppe vilde kunne trykkes. Samarbejde om en sådan opgave blev betragtet som udtryk for, at de enkelte personer ikke magtede selv at løse den stillede opgave - og derfor opgivet. Det var et velkomment og velgørende udtryk for brud på denne praksis, at to teologer i Ribe - biskoppen og stiftsprovsten - indbød fire yngre forskere - en sognepræst og tre cand.mag.'er - til »forskermøde « i Ribe. Hver især gjorde rede for sit projekt vedrørende Grundtvig, man fandt det værdifuldt at mødes igen, og årbogen »Grundtvig-Studier « blev besluttet efter forslag af biskop Hans Øllgaard, der ikke var til stede, og som dengang var den eneste af disse personer, der var kendt som grundtvigianer. Vi var altså hverken tilhængere eller modstandere af grundtvigianismen, kun tilhængere af en saglig Grundtvig-forskning.

Den samme holdning genkender jeg hos Grundtvig-Selskabets nuværende formand, når han i Grundtvig-Studier 198990 (s. 47) skriver, at Grundtvigforskningens opgave er den »at gøre rede for, hvad det var, Grundtvig mente og udtrykte«. Noget andet er »den sidste, eksistentielle tilegnelse «, som er hvert enkelt menneskes ansvar udfra forudsætninger, som er »individuelle og tidsbestemte «. Hvad der her er sagt om forholdet til Grundtvigs salmer, gælder efter min mening hele hans forfatterskab.

(At denne forskning ikke blot drives inden for GrundtvigSelskabet, men overalt, hvor en saglig debat finder sted om 
Grundtvig og hans virkning og eftervirkning, er en selvfølge. Grundtvig-Selskabet har blot oprettet et forum for den, der ikke gør krav på nogen »eneret til sandheden«.)

Men selv om der her er tale om to forskellige forhold til Grundtvig, hans forfatterskab og dets eftervirkninger: en rent saglig og en eksistentiel, der nødvendigvis må være personligt præget, kan det ikke undgås, at den saglige forskning og dens mundtlige og skriftlige udtryk bliver mere eller mindre præget af forskerens personlige forhold til det, hun eller han taler eller skriver om. Der er ingen »vandtætte skodder « mellem objektiv og subjektiv holdning til det, man undersøger. Man må være klar over forskellen mellem de to holdninger og så vidt muligt adskille dem. Det væsentlige er at fastholde den principielt saglige holdning, som det, der styrer forskningen.

Dette er for mig forudsætningen for Grundtvigdebatten.

2. Når jeg har spurgt Kim Arne Pedersen, »hvor han vil hen« med sit studium af Grundtvigs Danne-Virke-afhandlinger, er det ganske rigtigt et eksistentielt, dvs. personligt spørgsmål. Jeg er ikke i tvivl om, at han har ret i, at de tanker, Grundtvig dér udtrykker, er præget af hans skoling i den før-kantiske filosofi, som han er blevet undervist i på Københavns Universitet af professoren i filosofi Børge Riisbrigh. Dette er med fuldkommen overbevisende dokumentation klarlagt af Henning Høirup i hans disputats »Grundtvigs Syn paa Tro og Erkendelse« fra 1949 (den første danske Grundtvig-disputats overhovedet). Hvad jeg hævder, er, at denne før-kantiske tænkemåde hos Grundtvig, såvel i Danne-Virke som i »Udsigt over Verdens-Krøniken « (1817) er helt bevidst. Grundtvigs brug af »Modsigelsens Grundsætning som teologisk Aksiom « (Høirups undertitel på disputatsen), såvel i Danne-Virke som i striden med H.N. Clausen, er efter min mening ingen tankefejl, men en bevidst protest mod Kant og den efter-kantiske filosofi.

Grundtvig indlader sig ikke på en filosofisk begrundet kritik af Kant (hvem han i »Kort Begreb af Verdens-Krøniken« 1812 havde ydet sin store anerkendelse). Han nøjes med at opstille sit alternativ til Kants filosofi, et alternativ, der ganske rigtigt er begrundet i den før-kantiske filosofi, men tillige - og det er det væsentlige - i troen på den almægtige, treenige 
Gud, der ikke kan modsige sig selv, og hvis magt Grundtvig endnu i 1817 mente at kunne demonstrere ved en fremstilling af verdenshistoriens forløb.

Når Kim Arne Pedersen i sine »Hermeneutiske overvejelser« over læsningen af Danne-Virke-artiklerne tilstår sin "fascination « af den enhedsfilosofi, som fulgte efter Kant (Fichte, Schelling og Hegel), stiller han sig på samme standpunkt som flertallet af samtidens og eftertidens teologer i Danmark. Hensigten afsløres ikke i den danske tekst til hans artikel, der hovedsagelig indeholder en stort set udmærket sammenfatning af min fremstilling af Grundtvigs tænkning, men først i det engelske resumé, hvor det udtrykkelig hedder, at hans hensigt er »en ny fortolkning " (»a new interpretation«) af Grundtvigs Danne-Virke-artikler. Denne ny fortolkning er imidlertid $i$ princippet den samme som den, Henning Høirup har givet $\mathrm{i}$ sin disputats. Det spørgsmål bliver da stående, hvorvidt Kim Arne Pedersen anser det for muligt at forbinde denne før-kantiske tænkning med en efter-kantisk idealistisk enhedsfilosofi. Og om Grundtvig selv har anset dette for muligt.

Det var dette spørgsmål, jeg ønskede Kim Arne Pedersens svar på, da jeg spurgte, »hvor han vilde hen « med sine studier af forudsætningerne for Grundtvigs tænkning hos Wolff og Leibniz.

Dét er som sagt et eksistentielt, personligt spørgsmål. Og det kan jeg naturligvis ikke svare på. - Men jeg for min part tror ikke, det er muligt at forbinde hverken den kristne tro eller en kristen livsanskuelse med en idealistisk enhedsfilosofi. Det mener jeg at have loert af Grundtvig. Jeg anser Grundtvig for at være den bedste vejleder, jeg kender, når man - vel at mærke - ikke standser ved det punkt, han befandt sig på $\mathrm{i}$ 1812, 1814 eller 1817 (i sine tre »Verdenskrøniker «), men følger den udvikling, han gennemgik livet igennem, og ser, hvad der blev stående, og hvad han ændrede i sin holdning til samtidens videnskab og tænkemåde.

Så længe Grundtvig kun kendte Kants religionsfilosofi, dvs. i 1812, mente han, at det forbehold, der lå i titelen »Religjonen indenfor Fornuftens Grændser « (»Die Religion innerhalb der Grenzen der bloßen Vernunft $\ll)$, var nok til at sikre, at 
fornuften ikke tog magten fra troen. Da han i 1815 læste »Kritik der reinen Vernunft «, forstod han, at han havde taget fejl: fornuften havde taget magten fra troen, menneskets begrænsning var overskredet, og modsigelsens grundsætning var reduceret til en regel for den formelle logik. Derfor blev Grundtvigs vurdering af Kant en helt anden i Verdenskrøniken fra 1817.

Jeg er ikke i tvivl om, at Kim Arne Pedersen kan føje mange enkeltheder og nuancer (og naturligvis nye oplysninger) til den introduktion, jeg har givet til Grundtvigs Danne-Virkeartikler (såvel som til Grundtvigs forhold til naturvidenskaben). Men jeg må fastholde, at Grundtvigs hensigt var at hævde kristendommens uforenelighed med Kants og hans efterfølgeres idealistiske filosofi.

Og jeg må personlig give Grundtvig ret: en religion, der bygger sin sandhed på en eller anden filosofi, er ingen ægte religion. Den vil styrte sammen, når denne filosofi modsiges af virkeligheden. Grundtvig skriver i sin »Udsigt over VerdensKrøniken« 1817 om Leibniz i anledning af hans »Theodicée«: "...Støtter staae for Fald, og hvad der hviler paa dem, vakler, naar de rokkes, nær havde ogsaa en Discipel af Leibniz revet disse ned, før de vare opsatte, og denne Discipel, der vilde overgaae sin Mester ved at rive Kirken ned og bygge sig en Verden af Stumperne, var, som bekjendt, ingen anden end Christian Volf fra Breslau.« (S. 409).

Det forekommer mig efter disse ord umuligt at betragte Grundtvig blot som en elev af Leibniz og Wolff, skønt det er unægteligt, at hans lærer i filosofi var elev af dem.

En æate religion bygger efter min mening ikke på nogen filosofisk tankebygning, men på en overmenneskelig åbenbaring. Tro er menneskets forhold til det overmenneskelige, det, vi ikke kan klare med vor egen »fornuft eller kraft « (Luther). Dette var også Grundtvigs mening, og det er den, der ligger bag ved hans vurdering af Leibniz og Wolff trods alt, hvad han har lært af Børge Riisbrigh og læst af Wolff og Leibniz. En yderligere dokumentation heraf kan ses i »Udsigt over Verdens-Krøniken« 1817. Wolffs system kalder han s. 409 »Stilladset, han satte op for at rive ned«. I samme bog s. 435 kalder han det »det nye philosophiske Evangelium, hvori 
de tydske Boglærde snart fandt deres Salighed«, og karakteriserer det som »en naturlig Vidskab, der skulde gjøre Bibelen overflødig «. Det forhindrer imidlertid ikke, at han $\mathrm{g} \emptyset \mathrm{r}$ den indrømmelse, at det var Wolffs filosofi, der »først angav det eneste unægteligt sande Beviis for Guds Værelse og Tilværelse som et Væsen, der er af og $i$ sig selv ... angav siger jeg, thi udført og lovmæssig anvendt blev Beviset vistnok ingenlunde, da det ellers vilde knust den hele Bygning, der opførdes, ei efter Guds Billede, men efter Volfs Hoved i Luften." (S. 437438). Man kan læse Grundtvigs videre udførelse af denne kritik i denne hans tredie og udførligste Verdenskrønike (VK 1817 s. $438-441)$.

Jeg er ikke teolog eller filosofihistoriker, men litteraturforsker, og min metode som grundtvigforsker er idehistorisk. Metoden er ikke sandheden, men et redskab til at finde svar på en problemstilling. Min overordnede problemstilling mht. Grundtvig er denne: hvori bestod det saregne ved Grundtvigs digtning og toenkning? - Det er dette spørgsmål, der ligger bag mine studier over Grundtvigs Verdenskrøniker og i nærmeste forbindelse hermed over de filosofiske betragtninger af menneskelivet, som blev nødvendige, når Grundtvig vilde forsvare sit bibelske (»mosaisk-christelige «) historiesyn. Han kom derved til at indtage en særegen plads i dansk og europæisk litteratur: han forsvarede en livsanskuelse, som for længst var forladt af de ledende og dominerende $\mathrm{i}$ hans samtid. Det vil derfor være umuligt at forstå hans tænkning som et led i samtidens sædvanlige tænkning, og heller ikke som en fortsættelse af den umiddelbart foregående tids tænkning.

Det var på denne måde, Grundtvig blev en selvstoendig tæenker. Han kan hverken betragtes blot som skolet i et bestemt system og viderefører af det, eller som en eklektiker, der tog, hvad han kunde bruge hos de forskellige tænkere, han havde læst. Hans plan var at blive historiker og bygge sin tænkning på erfaringen - og historien som menneskehedens erfaring. Den »sunde Menneskeforstand «, han føjede til i sin første filosofiske betragtning af menneskelivet, var dels den elementære logik og dels hvad man i filosofihistorien kalder »den naive realisme «, dvs. vor normale, dagligdags virkelighedsopfatelse. 
Den eneste samtidige tænker, som Grundtvig en kort tid var grebet af, var Schelling. Det ses klart af hans dagbog og hans første afhandling »Om Religion og Liturgie« (1806). Forholdet til Schelling er behandlet i C.I. Scharlings bog "Grundtvig og Romantiken « (1947), som blev forelagt i trykfærdig stand ved det forskermøde, der førte til Grundtvig-Selskabets stiftelse, og som jeg har anmeldt i 1 . bind af Grundtvig-Studier. Bogen er vigtig, fordi den afliver den opfattelse, Edvard Lehmann 1931 hævdede i sin Grundtvigbog, at Grundtvig ligefrem var elev af Schelling og altså filosofisk idealist. Men Scharling gør ligesom Grundtvig selv opmærksom på, at Grundtvig også efter 1810 kunde give Schelling ret, hvor han fandt, at han havde ret. Det er dette, der ses i manuskriptet »Grenzen der Menschheit«, som jeg har behandlet i min første introduktionsartikel til Danne-Virke. - En anden vigtig ting i Scharlings bog er, at han har fremsat den teori, at det var kendskabet til Schellings filosofi, der gav Grundtvig ideen til den helhedsopfattelse af den nordiske mytologi, han udtrykte i artiklen »Om Asalæren« 1807 og »Nordens Mytologi« 1808. Det forklarer nemlig det spændte forhold mellem den kristne og den før-kristne religion, der kom til at bestå i Grundtvigs indre i årene 18111832.

Som litteraturhistoriker med idehistorisk metode må jeg naturligvis registrere disse væsentlige forudsætninger for Grundtvigs tænkning og digtning. De er også forudsætninger for den religiøse krise, Grundtvig kom ud i, da hans far vilde have ham til sin hjælpepræst. Men jeg kan ikke forstå Grundtvigs forfatterskab, herunder hans tre Verdenskrøniker og tidsskriftet Danne-Virke, uden at konstatere hans holdning til de påvirkninger, han møder - og de cendringer $i$ hans holdning, som tydeligt fremgår af hans trykte og utrykte skrifter. Det er derom mine Grundtvigstudier handler: Siger Grundtvig ja eller nej til det, han her beskriver, de forfattere, han omtaler, den udvikling i europæisk åndsliv, han skildrer i sine Verdenskrøniker? - Det er denne form for kritik, der karakteriserer Grundtvig som forfatter og som menneske. Den er totalt forskellig fra den historiske kildekritik og bibelkritik, som samtiden udviklede. 
Jeg har vist (i Grundtvig-Studier 1991 som i min disputats 1954), at den ændrede holdning til Schelling og den efterkantiske idealistiske filosofi, Schelling repræsenterer, allerede ses $\mathrm{i}$ fortalen til Grundtvigs dimisprædiken april 1810. Men konsekvenserne af krisen i efteråret 1810 ses tydeligt i hele hans forfatterskab fra det følgende år til hans død. Forholdet til Schelling og til den nordiske mytologi er væentlige forudsætninger for hele denne udvikling - som har stor interesse for nutiden, fordi hele nutidens livsopfattelse har fortsat den udvikling, Grundtvig livet igennem kæmpede imod, fordi han forstod de farer, det vilde føre med sig at forlade kristendommen som livsgrundlag. Han betragede den idealistiske filosofi og teologi som et falsk forlig mellem den ægte kristendom og samtiden. Men at dette synspunkt også vilde bringe ham i konflikt med Kant, forstod han først ved mødet med »Kritik der reinen Vernunft « i 1815. Der er altså tale om en personlig religiøs udvikling, der kan spores gennem hele forfatterskabet til hans sidste digt.

Ud fra denne metode og med denne problemstilling forekommer det mig ganske rimeligt, at jeg $\mathrm{i}$ min behandling af manuskriptet »Grenzen der Menschheit « skelner mellem, hvad Grundtvig anerkender hos Schelling, og hvad han som kristen må vende sig imod.

3. Det fremgår vist klart af min artikel i forrige årgang af Grundtvig-Studier om »Vejen fra tvang til frihed i Grundtvigs liv og forfatterskab «, at hensigten ikke har været at modsige Kaj Thanings disputats »Menneske først -«(1963). Jeg har tværtimod erklæret mig enig med ham i mange henseender og er ikke i tvivl om det rigtige i påvisningen af den forbløffende forskel, der er mellem Grundtvigs holdning over for samtiden før og efter 1832. Min problemstilling i denne artikel er imidlertid en anden end Thanings, og deraf kommer den forskel i behandlingen af de samme tekster og tekststeder, som enhver kan se, og som det vilde være meningsløst af mig at ville påstå urigtigheden af. Vi ser teksterne fra forskelligt synspunkt, og derfor tager de sig forskelligt ud.

Det er naturligvis rigtigt, at hensigten med Grundtvigs lille skrift »Om den Clausenske Injuriesag« ikke er at gøre Clausen nogen indrømmelser. Men det forhindrer ikke, at den for 
mit synspunkt vigtige indrømmelse alligevel slipper ud i den sidste lange og meget velformede sætningskæde. Vandskellet i Grundtvigs forfatterskab er, både fra Thanings og mit synspunkt »Nordens Mythologi« 1832. Jeg har imidlertid tilføjet den væsentlige forklaring herpå, at Grundtvig, da han var blevet præst i 1811, så sig tvungen til at tage afstand fra »den livsopfattelse, der havde ført ham tilbage til en religiøs livstydning overhovedet «, nemlig den nordiske mytologi. Thaning har naturligvis ret $\mathrm{i}$, at forholdet mellem menneskelivet og kristendommen var hovedproblemet i Grundtvigs liv, og at dette problem først fik sin løsning i 1832. Han har også ret i, at det var indre årsager, der førte til de brud, der fandt sted i Grundtvigs personlige udvikling. Men disse brud fremkaldtes ikke des mindre af ydre forhold. Og dermed tænker jeg ikke blot på forældrenes krav til ham i 1810. Jeg tænker også på statskirkens krav til enhver præst.

Når man er præst, bliver man nødt til at se forholdet mellem menneskeliv og kristendom som et teologisk problem. Men vi andre, som ikke er præster eller teologer, vi ser jo sagen fra det naturlige synspunkt: »Menneske først og kristen så «. For mig at se var det dette synspunkt, der fik betydning for Grundtvig i 1832, selv om formuleringen deraf i digtet er 5 år senere. - Thaning mener, at Grundtvig fik et nyt »livssyn « fra dette år, fordi han fik øje på menneskelivet, men det havde han jo hele tiden haft øje for. Sagen er fra mit synspunkt den, at han fra sin ordination i 1811 havde følt sig tvungen til at se problemet som et teologisk problem, der stillede det krav til ham, at han skulde pånøde eller påtvinge samtiden det bibelske historiesyn og fra 1825 den apostolske trosbekendelses kristendom. Det væsentlige er fra mit synspunkt ikke kristendomsopfattelsen, men simpelthen rakkefølgen: vi er mennesker, før vi bliver kristne.

For mig at se er der ingen virkelig forskel mellem Thanings og min opfattelse af hovedproblemet i Grundtvigs liv og løsningen af det. Forskellen består deri, at sagen tager sig forskellig ud for en teolog og præst på den ene side og for en kristen litteraturhistoriker på den anden side. - Man må ikke misforstå mig, som om jeg overtog Thanings synspunkt eller vilde påtvinge ham mit. Jeg vil blot gøre opmærksom på, at 
sagen nødvendigvis tager sig anderledes ud for den, der som jeg ikke er præst, men dog kristen. Præsteløftet er ikke så alvorligt i dag, som det var i 1811. Men det var efter min opfattelse det, der gjorde, at Grundtvig opfattede det som sin pligt at pånøde sin samtid kristendommen. -

Jeg vilde sige: »Der er faldet skæl fra Grundtvigs øjne, da han besluttede at skrive den nye Nordens Mythologi.« Sådan vilde jeg udtrykke det nye livssyn, Thaning taler om. Han turde skrive den bog uden at være bange for at miste sin kristendom derved.

Han var fri og kunde frit sige ja til at blive præst for en menighed, der gerne vilde have ham. Han kunde frit beskrive sin elskede nordiske mytologi som et symbolsprog, der lod sig forklare historisk og betragte poetisk - uden at han derfor gjorde det til sin religion. Det var dette forhold, han gav sin begrundelse og forklaring på i den lange indledning, der udtrykker det, der i de forløbne år havde været hans personlige problem.

Det væsentlige fra mit synspunkt er, at Grundtvig har opgivet at ville demonstrere kristendommens sandhed ved historiens hjælp. Det er og bliver en tro, der hænger uløseligt sammen med den mosaisk-kristelige anskuelse, som derfor er »den eneste guddomelig sande og eviggiældende «. Og denne nye holdning beror på, at Grundtvig har opdaget, at troen må være en fri sag, hvis den overhovedet skal være ærlig og sand. - Dette fører igen til dét nye kulturprogram, der antydes i fortalen til Verdens-Historien 1833: adskillelsen af Kirke, Stat og Skole, dvs. religion, politik og videnskab.

4. Det er muligt, at nogen vil betragte min villighed til at indrømme berettigelsen af andre synspunkter end mit eget som et svaghedstegn. Sådan betragter jeg ikke sagen selv. Jeg finder tværtimod, at vi i Grundtvigforskningen som i de humanistiske videnskaber overhovedet har brug for at anerkende forskellige synspunkter. Det er bl.a. en forudsætning for samarbejde og team-work - især når det drejer sig om et så rigt og omfattende område som Grundtvigs liv og forfatterskab og dets eftervirkninger. 